\title{
Combating Terrorism by Constraining Charities? Charity and Counterterrorism Legislation Before and After 9/11
}

Nicole Bolleyer, University of Exeter, and Anika Gauja, University of Sydney

Forthcoming: Public Administration

\begin{abstract}
:
How does counter-terrorism legislation - enacted in democratic states - impact upon charities, intentionally or unintentionally? To address this question, we present a new analytical framework that allows us to compare, across established democracies, how charity and counterterrorism legislation are connected, enabling us to assess how charities' legal environments have changed since 9/11. Comparing legislation across six long-lived democracies (UK, US, Australia, New Zealand, Canada and Ireland), we distinguish between three types of legislative connection: overlap, direct intersection and indirect intersection. These categories differ in terms of the visibility of the connection established between the two areas of law. As high profile reform exercises, both overlap and direct intersections have been predominantly introduced post-9/11. But it is through indirect intersections that intensified post $9 / 11$ which are most vague and difficult to manoeuvre, that the day-to-day activities of charities are most likely to be affected, with important empirical and normative repercussions.
\end{abstract}

\section{Keywords:}

Charities; counterterrorism law; charity law; legal change; reform; 9/11 attacks, comparative analysis; common law democracies 


\section{Introduction}

To what extent does legislation aiming to combat terrorism in democratic states apply either intentionally or unintentionally, to charities? To address this question, this article proposes a novel, organization-centred analytical framework that can be used in comparative analysis to comprehensively assess how charity and counterterrorism laws connect, and, if so, how they constrain charities across different jurisdictions. Distinguishing between legislative overlap, direct and indirect intersection, we then apply these categories to legislation adopted in six long-lived democracies: Australia, Canada, Ireland, New Zealand, the UK and the US in the post 9/11 period.

The paper focuses on legislation applicable to voluntary organizations that enjoy charitable status ('charities') for several reasons. ${ }^{1}$ Charities are an important subset of civil society; traditionally less regulated than for-profit organisations (Hopt and von Hippel 2010), but since the $9 / 11$ attacks have been considered particularly vulnerable to abuse in several ways (Krahmann 2005). Terrorist groups may pose as charities to have a legitimate front for their activities, for example, to channel funding or to collect donations (e.g. Raphaeli 2003). Charitable status is particularly attractive since these organizations receive privileged treatment by the tax authorities, both through tax relief granted to the organization directly and indirectly to its donors (e.g. Salamon 1997; Bater et al. 2004). Another scenario sees potential for terrorist abuse in the exploitation of particularly humanitarian charities that operate internationally (including in areas where terrorist groups might be active), with the purpose of channelling money to supporters abroad, with the charity being unaware of this activity (e.g. Bricknell 2011; Freeman 2011; FATF 2014). ${ }^{2}$

However, the vast majority of organizations that make up the charitable sectors of democracies match none of these scenarios, ${ }^{3}$ but are still affected by the consequences of

\footnotetext{
${ }^{1}$ The specific definition of a charity varies across jurisdictions, but generally refers to a non-profit organization that exists to undertake a charitable purpose beneficial to the general public (e.g., advancing health or education). For so doing it is granted a particular legal form and/or receives preferential treatment under tax law (see on this, for instance, O'Halloran 2011).

${ }^{2}$ For empirical examples, see Moor (2010); Young (2013); Goodstein (2008); CRA (2016a); Cole (2016); Charities Services (NZ) (2016).

${ }^{3}$ See, for instance, a recent report by the Charity Commission of England and Wales (2015). While terrorist and extremist-related allegations accounted for 22\% of all disclosures in 2014/15,
} 
enhanced counterterrorism legislation, for example, through exposure to increased regulatory burdens, leading to fewer donations and/or the loss of services supplied by financial providers (such as banks). ${ }^{4}$ Charities are particularly sensitive to compliance costs as they are less able than for profits to pass on these additional costs to donors or government grantors, thereby decreasing public good production (Garton 2009). Consequently, they have responded to 'the real or perceived threat of criminal liability' by pre-emptively withdrawing from some of the activities that could bring them into conflict with counterterrorism legislation before it is even invoked (Carter 2004, p.1; Burniske 2014, pp. 6-8; Bloodgood and Tremblay-Boire 2011).

Systematically assessing the organizational impact of counter-terrorism legislation is crucial as the costs and unintended side effects of charity regulation post 9/11 become increasingly recognized. For example, in June 2016, the Financial Action Task Force (FATF), an international standard-setting body producing (non-binding) recommendations on antimoney laundering and counterterrorism financing, removed its advice in 'Recommendation IIV' that non-profit organizations were 'particularly vulnerable' to terrorist exploitation - a much criticized claim backed by little empirical evidence (Cortright et al. 2012, p. 249). ${ }^{5}$ Previously considered influential in pushing its member states towards a stricter regulation of charities and non-profits (Howell 2012, p. 46; NCVO 2009), the FATF's revision acknowledged that not all non-profits are at risk and directed countries to take a risk-based, proportionate approach towards the sector, a move considered to be a major reorientation by stakeholders. ${ }^{6}$ Any such reorientation of regulatory approach presupposes, however, an understanding of the extant risks and costs faced by 'innocent' charities as generated by the

compared to $14 \%$ the year before, only two of 11 serious incident reports that related to extremism involved charities whose staff or goods had been seized by terrorist groups. (In contrast, nearly 1500 serious incident reports related to safeguarding and financial mismanagement). Similarly, experts indicate that of 1.8 million charitable organizations in the US only a handful have been alleged to have links with terrorism financing (Cortright et al. 2012, p. 249).

${ }^{4}$ See on this, for instance, Cortright et al. (2012), Mackintosh and Duplat (2013), Keatinge (2014), FATF (2014), Rutzgen 2015.

${ }^{5}$ See http://www.fatfgafi.org/media/fatf/documents/recommendations/pdfs/FATF_Recommendations.pdf, accessed October 302016.

${ }^{6}$ See, for instance:

http://www.icnl.org/news/2016/2016\%2006\%20NPOs\%20applaud\%20important\%20changes\%20in \%20Financial\%20Action\%20Task\%20Force\%20(FATF)\%20policy.pdf, accessed October 312016. 
national legislation and sanction regimes that evolved in the post $9 / 11$ period. ${ }^{7}$ This paper provides such an assessment.

The paper also builds on previous scholarship by systematically specifying mechanics of 'how' laws affect organizations, and proposing a comparative methodology for analysing this. A range of excellent in-depth analyses - both comparative and case-oriented - have been published since 2001 assessing how public policy has been shaped by the aspiration to combat terrorism and its impact on the voluntary sector. ${ }^{8}$ However, in order to evaluate how charity-affecting counterterrorism legislation varies across jurisdictions and over time, we need suitable tools for the comparative analysis of legislation: tools that can identify and capture the extent to which charities are affected by legislation that is not specifically directed at them. Formulating such tools allowing for an 'unbiased' cross-national analysis has proved challenging for comparative policy studies, legal and political science scholars. ${ }^{9}$ This is because focusing one's empirical analysis on statutes naming charities explicitly as a regulatory target risks overestimating the constraints on charities in jurisdictions that tend towards adopting very specific terms as compared to those that prefer to apply broad encompassing legal concepts. We argue that it is both methodologically and normatively important to consider how vague legal concepts such as 'unlawful group' or 'supporters' used by legislators. Such concepts not only enable the encroachment of counterterrorism legislation upon the liberties of collective voluntary sector actors (such as charities), they also are less visible than legislation explicitly targeting specific types of organisations or actors (e.g. Boyne 2004; Sidel 2010).

Beyond highly salient debates around counterterrorism and its repercussions for democracies, the research has direct significance for policy-makers. Understanding how legal environments affect organizations, intentionally or unintentionally, sits at the core of

\footnotetext{
${ }^{7}$ An important debate concerns the attempts of governments of non-democratic regimes to use legal means to control or actively manage civil societies (e.g. Rutzen 2015). That said, in democratic states we focus on we can assume that those effects are unintended or at least considered undesirable.

${ }^{8}$ See, for instance, Baron 2004; Howell 2006; Bell 2008; Sidel 2010; Bloodgood and Tremblay-Boire 2011; Carter 2011.

${ }^{9}$ In the following areas the problem has been more explicitly addressed: see, for instance, Biezen's work on comparative party law and constitutionalization (2012) or recent work on the cross-national assessment of policy change (Bauer and Knill 2014; Bauer et al. 2012).
} 
much public policy scholarship. For some scholars, unintended consequences are inevitable, but others note the potential for studies of policy outcomes to help policy-makers by anticipating and hence minimising unwanted impacts (Marsh and McConnell 2010, pp. 57980; 6 2014. pp.689-90). With 'law enforcement' being one of four major types of counterterrorism strategy and legislation providing its foundation (Sitter and Parker 2014, p. 163), this article contributes to this broad debate by presenting and empirically applying an analytical framework that can help scholars and policy-makers understand how different legislative regimes interact, over time and across jurisdictions, providing one important precondition for in-depth analyses of the actual consequences for voluntary actors when operating in distinct legislative environments. Essentially, we argue that the impact of legislation cannot be fully captured by reference to its explicit targets, but requires a more nuanced (yet systematic) assessment of its broader applicability to actors not necessarily named in it.

In the following, we present a novel, organization-centred analytical framework for comparative legal analysis that distinguishes between three categories - legislative overlap, direct intersection and indirect intersection - that allow us to assess the connections between charity and counterterrorism law. After justifying our period of study and the case selection, we assess the differences in legislation and their evolution across our six jurisdictions category by category, concluding with a discussion of the constraints the respective legal frameworks might impose on charities, and avenues for future research.

\section{How to Study the Connections between Charity and Counterterrorism Legislation Cross- Nationally}

A fundamental challenge for any cross-national assessment of legislation - irrespective of subject area or disciplinary perspective - is that similar phenomena, themes or problems are often regulated in different areas of legislation in different countries (Zweigert and Kötz 1998). While a 'functional perspective', that is, one focused on particular policy areas, allows us to engage in systematic comparison across different legal systems it does not address the problem of capturing the regulatory impact of legislation on organizations not explicitly named by it, which can create a misleading picture when trying to compare legal environments in which organizations operate. Therefore, to arrive at a comprehensive 
identification of legislation relevant to charities in each jurisdiction analysed, we approach regulation from a novel 'organization-centred perspective'. We ask - taking the viewpoint of a charity pursuing its goals (including the maintenance of its preferential status) - what direct and indirect constraints an organization is exposed to as a consequence of legislation that attempts to prevent terrorist abuse, whether naming charities explicitly or not.

As the foundation for our comparative analysis, we define counterterrorist legislation broadly as legislation aimed at preventing actions - or the threat of these actions - that advance a political, religious or ideological cause and attempt through the systematic and premeditated use or threatened use of violence against civilians (and personnel not engaged in combat operations) to coerce a government and/ or intimidate the public (Jackson et al. 2005, p. 1; Tosini 2007, p. 667; Lynch et al. 2015, pp. 15-6). To capture legislation that implicitly affects charities as collective actors, legislation concerned with the activities of terrorist organizations and their supporters is of particular relevance. A terrorist organization is defined as a group 'that has chosen to utilize terrorism' as a tactic (Jackson et al 2005 , p. 1). ${ }^{10}$ This perspective avoids the pitfall of focusing on specific areas of law risking a biased cross-national assessment. Simultaneously, it systematically excludes counterterrorism legislation not immediately relevant to charities.

To systematically assess the nature of the connections that might exist between charity and counterterrorism legislation and their implications, we propose an analytical framework that distinguishes between three different types of connection: 'legislative overlap', 'direct intersection' and 'indirect intersection' (Table 1). The tighter a connection is, the more visible the constraints inherent in any attempt to counter terrorism through legislation applicable to charities are likely to be. By distinguishing between, and systematically considering, these three categories in our analysis we avoid concluding that regimes that opt for more visible connections target charities more in their attempts to counter terrorism through formal-legal means than those that tend to target charities more indirectly.

\footnotetext{
${ }^{10}$ As Golder and Williams (2004, p. 288) note, 'in jurisdictions that have attempted to formulate a general definition of terrorism, the basic sense of what is meant by 'terrorism' has not proven to be too elusive'. Beyond this, however, we have provided in Appendix A a more detailed comparison of how terrorism is defined in each of our six jurisdictions.
} 
Table 1: Categories for the Comparative Analysis of the Connections between Charity and Counterterrorism Legislation

\begin{tabular}{|l|c|}
\hline $\begin{array}{l}\text { Type of Connection between } \\
\text { Charity and Counterterrorism } \\
\text { Legislation }\end{array}$ & Relevant Type of Legislation* \\
\hline Overlap & $\begin{array}{l}\text { Counterterrorism legislation with charities as the main or } \\
\text { exclusive regulatory focus; } \\
\text { Charity legislation directed towards the combat of terrorism }\end{array}$ \\
\hline Direct Intersection & $\begin{array}{ll}\text { Charity legislation referring to the prevention of terrorism as one } \\
\text { goal; } \\
\text { Counterterrorism legislation with charities as one regulatory } \\
\text { focus }\end{array}$ \\
\hline Indirect Intersection & $\begin{array}{l}\text { Counterterrorism legislation applicable to charities through the } \\
\text { use of inclusive concepts (e.g. 'group', 'organization') or through } \\
\text { derivative offences (without explicitly mentioning charities) }\end{array}$ \\
\hline
\end{tabular}

*Note: Counterterrorism law is functionally defined and does not necessarily refer to separate pieces of legislation solely dedicated to the combat of terrorist activities. Similarly, charity legislation need not be labelled 'charity law' to be included in the analysis (e.g. charities can be regulated in tax codes).

The first category covers counterterrorism legislation with charities as the main subject (or target) or, vice versa, charity legislation directed towards the combat of terrorism ('overlap'). The second category covers charity legislation explicitly referring to the prevention of terrorism or directly related offences (e.g. terrorist financing) and, vice versa, counterterrorism law with charities as one explicit (but not the only or main) regulatory focus ('direct intersection').

The third category 'indirect intersection' is the most inclusive, yet the least visible. Reflecting our organization-centred perspective, it comprises counterterrorism law, which through the measures it provides for the proscription or listing of terrorist groups, affects the operations of charities through the use of inclusive concepts (such as 'group', 'organization'), and through the derivative offences attached to them. Three elements are particularly crucial here: first, whether it is necessary that charities know that they are dealing with a terrorist group in order to commit an offence, or whether they can commit an offence by, for instance, not making sufficient efforts to establish whether any of their partners are linked to such a group; second, how loosely or broadly 'involvement with 'or 'support for' such a group is defined; and third, how strictly forms of involvement or support are sanctioned. 
The first two elements, in particular, contribute to the uncertainties charities face when trying to manoeuvre legal constraints. While we may intuitively perceive the explicit targeting of charities (e.g. through legislative overlap) as particularly problematic, it is the less immediate connections that might generate a higher level of uncertainty for charities regarding whether and how rules concern them and where the boundary between legal and illegal behaviour lies. This highlights the fact that the relative visibility of connections as captured by our three analytical categories (more pronounced in instances of overlap or direct intersection than indirect intersection) cannot serve as a proxy for the scope or nature of constraints imposed by the different legal frameworks analysed. Rather, it is an assessment that needs to follow an initial characterization of the range of legislative connections a legal framework establishes.

\section{Period of Study and Case Selection}

We apply our framework to the post-9/11 period, which has seen counterterrorism legislation introduced or strengthened in many democracies around the world. While calls for, and a shift towards, stronger government oversight of the voluntary sector did not necessarily start with the $9 / 11$ attacks, the links between voluntary-sector and counterterrorism legislation have grown substantially during this period as attempts to strengthen counterterrorism legislation have gone well beyond the specific area of terrorist financing that initially attracted particular attention. ${ }^{11}$ As $\mathrm{O}^{\prime}$ Halloran (2011, pp. 106, 109-10, 198) has pointed out, governments have tended to use terrorist threats as an excuse to tighten charity surveillance, intensifying the connection between these two areas of law. These changes are on-going: in 2016, the Charities (Protection and Social Investment) Act (UK) was passed, which for the first time explicitly connected these two policy areas in the UK. This stresses the topic's lasting saliency and policy relevance; even in countries that in recent years were spared from any major attacks.

\footnotetext{
${ }^{11}$ Since 2001 various international initiatives, for instance the FATF (mentioned earlier), have pushed for a more tightly regulated voluntary sector.
} 
The six long-lived democracies Australia, Canada, Ireland, New Zealand, the UK and the US constitute a suitable set of cases in which to comparatively assess the relationship between charity and counterterrorism legislation. They are - in terms of legal traditions and political culture - most similar (O'Halloran 2011) and (with the exception of Ireland) cooperate together sharing security intelligence under the 'Five Eyes' agreement. Due to a shared liberal heritage they are commonly considered as weakly disposed towards the adoption of rights-restrictive measures as far as fundamental individual or group rights are concerned. As this type of legal regulation is perceived as particularly contentious in democracies with strong liberal traditions, these countries therefore methodologically constitute 'least likely cases' (Gerring 2007) for intense legal interference in the charitable sector. Consequently, the detection of such interference particularly stresses the wider empirical importance of these developments, as they are, if anything, likely to be more pronounced in systems with strong traditions of 'democratic self-defence' such as France or Germany (Thiel 2009).

Simultaneously, our six jurisdictions show considerable variation in their exposure to internal and international terrorism. ${ }^{12}$ This variation is important as we might expect greater regulation in response to significant domestic terrorist attacks. Tighter connections between charity and counterterrorism law may also emerge as countries (including those not exposed to terrorism) honour international commitments or emulate policies observed in other jurisdictions. If substantiated empirically, the implications for democratic civil societies are more far-fetching than if such connections were simply 'functional' responses to actual terrorist incidents in individual jurisdictions.

\footnotetext{
${ }^{12}$ UK and Ireland have (unlike the other jurisdictions) long-standing experience with internal terrorism. New Zealand, Australia and Canada have not been exposed to significant internal or international terrorist attacks compared with the major casualties experienced by the US, UK and Ireland. Note that while most violence the Republic of Ireland was exposed to took place on Northern Irish soil, studies show that the society in the Republic was directly affected by this. For instance, Hayes and McAllister (2005) found similar levels of support for the use of violence for political ends in Northern Ireland and the Republic pointing to a close interaction between constitutional and extraconstitutional politics across the Irish border (Hayes and McAllister 2005: 607-8), making the fight against terrorist activity a salient problem across Ireland. The passing of the Irish Offences Against the State Act of 1939 illustrates this. This law introduced major provisions allowing the state to declare groups 'unlawful' still inforce today (see details below). It was introduced in the context of the IRA launching a short-lived bombing campaign in the UK that was interpreted as a direct threat to parliamentary institutions and political parties in the Republic (Lombart 2011).
} 


\section{Analysis: Connections between Charity and Counterterrorism Legislation in Six Democracies}

While our analytical categories are applicable to hard as well as soft law, we focus on statutory legislation to assess the implications of charitable organizations' formal-legal environment. For the US analysis, we include executive orders, which are formally binding and therefore the major constraints confronting organizations. Echoing earlier research (e.g. Nohrstedt and Hansén 2010), international agreements central to the introduction of statutory law are also covered in our contextual analysis. ${ }^{13}$ Applying each category one by one, we assess what type of connection exists in each jurisdiction, when it was introduced (before or after 9/11), and amended. ${ }^{14}$

\section{The Introduction of Legislative Overlap post 9/11}

All cases of overlap occurred either in the US or Canada, right after the 9/11 attacks. They are the Charities Registration (Security Information) Act 2001 (CRSIA) in Canada; and, in the US, the USAID Anti-Terrorism Certification and the certification requirements in the Combined Federal Campaign Program. Insofar as governments need to signal clear legislative intent in the aftermath of a crisis, visible regulatory connections based on legislative overlap send a clear message to organizations that might want to exploit the privileges that charities enjoy under a given regime. That said, the CRISA regulates only rare situations where classified intelligence information is needed to refuse an organization from registering as a charity (or deregister an organization) as regulated under the Income Tax Act 1985 (sec. 230 to 231.5). ${ }^{15}$ This is allowed when there are 'reasonable grounds' to believe that the organization has engaged (directly or indirectly) or will engage in terrorist activities (Carter 2011, pp. 31-33). ${ }^{16}$ More significantly for the charitable sector, the US Acquisition and Assistance Policy Directive 02-19 (2002) requires an 'Anti-Terrorism Certificate' from organizations entering into an assistance agreement with USAID that

\footnotetext{
${ }^{13}$ See for a detailed justification of the empirical scope of our analysis see Appendix B. ${ }^{14}$ See Appendix $\mathrm{C}$ for the primary sources assessed.

${ }^{15}$ http://www.cra-arc.gc.ca/chrts-gvng/chrts/ntrntnl-eng.html, accessed July 262016.

${ }^{16}$ For instance, in 2011, the CRA revoked the charity registration of IRFAN-Canada, believed to have supported Hamas, a listed terrorist organization (CRA 2016c).
} 
assures to the latter they do not support terrorist activities or organizations. ${ }^{17}$ Similarly, the rules of the Combined Federal Campaign (CFC) (through which thousands federal employees donate to charities), require participating organizations to certify that they do not knowingly employ anyone or provide funds to terrorist organizations (FATF 2006, p. 246). ${ }^{18}$

\section{The Introduction and Expansion of Direct Intersections post 9/11}

Only the US had established direct intersections between charity and counterterrorism law prior to 9/11. All other countries introduced them afterwards: Canada and New Zealand in 2001 and 2005, Ireland in 2009, Australia in 2012 and finally the UK in 2016. In all jurisdictions but Canada (which regulated the area through regulatory overlap, see above), these intersections deal with charity (de)registration. Except for New Zealand and Ireland (where direct intersections are restricted to registration), all other countries give their respective charity regulators explicit powers to monitor or inspect charities suspected of counterterrorism offences (see Table 2, below).

In New Zealand, designated terrorist entities cannot register under the Charities Act 2005 (s. 4(1)), neither can those convicted of offences under the Terrorism Suppression Act 2002 (s. 6A to 13E). Similarly, the Irish Charities Act 2009 specifies that a 'charitable organisation' 'shall not include an excluded body' which covers organizations 'in support of terrorism or terrorist activities' (s. 2; Art. 43 (1) and 44 (1)). In the US, a direct intersection had already been created in the 1990s following earlier terrorist attacks. Since then, the Internal Revenue Code (IRC, 26 U.S.C) has contained a provision barring 501(c)(3) organizations from diverting funds for non-charitable purposes, including terrorism. Post 9/11 provisions

\footnotetext{
${ }^{17}$ AusAID, in contrast, does not have a specific policy on counter-terrorism but requires organizations which apply for accreditation to be a compliant signatory to the Australian Council for International Development (ACFID) Code of Conduct for Non-Government Development Organizations. This (in principle) voluntary code includes provisions that funds are used in accordance with the law, including counterterrorism legislation (Mackintosh and Duplat 2013, p. 49). ${ }^{18}$ The Anti-Terrorist Financing Guidelines: Voluntary Best Practices for US-based Charities, issued by the US Treasury Department constitutes an instance of overlap, when applying our categories to 'soft law', These guidelines have raised concerns about the blurring between government guidance and statutory obligation as they contained a broad and detailed list of provisions to be applied by charities and philanthropic organizations in their overseas giving. They were revised after widespread criticism in the sector (Sidel 2010, pp. 17-19).
} 
suspended all designated terrorist organizations from receiving tax-exempt status (Bloodgood and Tremblais-Boire 2011, p. 151).

Beyond dealing with registration, the Tax Exempt and Government Entities Division of the IRS regulates and monitors exempt organizations through the examination of returns and compliance checks, with an emphasis on assuring that exempt organizations continue to meet their statutory requirements (Hopkins 2008). Similarly, the Charities Directory within the Canadian Revenue Agency monitors charities' violations of the 2001 Anti-Terrorism Act, for which it formally established a 'review and analysis division' in $2003 .{ }^{19}$ In Australia we find, as in the US, direct intersections regarding charity registration ${ }^{20}$ and monitoring. One explicit objective of the charity regulator established by the Australian Charities and NotFor-Profits Commission Act 2012 (ACNC Act) is the prevention of the abuse of charity finances such as for terrorist purposes (s. 50.5). Consequently, the regulator is entitled to monitor compliance with provisions of the Crimes Act 1914 or the Criminal Code, which contain counterterrorism measures (ACNC Act, 75-5(c)). ${ }^{21}$ Until February 2016, the UK, or more precisely, England and Wales, ${ }^{22}$ was the only jurisdiction in which charity regulation did not explicitly refer to the prevention of terrorist abuse. This changed with the Charities (Protection and Social Investment) Act 2016. Establishing a strong intersection between charity and counterterrorism legislation, the Charities (Protection and Social Investment) Act strengthens the powers of the Charities Commission, responding, next to other issues, to concerns about the abuse of charities to support terrorism. Amending the Charities Act 2011, the Act creates a new list of offences that automatically disqualify a person from being a charity trustee under a range of conditions (e.g. being involved in money laundering or various terrorism offences under the Counter-Terrorism Act 2008 or the Terrorism Act 2000). These conditions, however, need not necessarily amount to a conviction: an attempt

\footnotetext{
19 http://www.canadiancharitylaw.ca/blog/cra presentation to finance committee on terrorism, accessed July 62016.

${ }^{20}$ See the Australian Charities and Not-For-Profits Commission Act 2012 (ACNC Act), ss. 25-5, 3 (d).

${ }^{21}$ As an example of a direct intersection in self-regulation, the Australian Council for International Development (ACFID) requires its members to sign a 'Code of Conduct' setting standards for financial transparency and accountability including the expectation that ACFID Members, before entering into any partnerships or employing staff, check all relevant lists of known terrorist individuals and organisations (Blacher 2016).

${ }^{22}$ Note that charity legislation in the UK is devolved with separate laws in place in Scotland in Northern Ireland. We refer to legislation adopted in England and Wales as the largest jurisdiction.
} 
to commit or incite an act that falls under the ambit of counterterrorism legislation also constitutes grounds for disqualification. Critics have argued that the new legislation risks blurring the boundary between the legal obligations trustees have to comply with and nonbinding guidance, as the Commission could treat failure to follow non-binding, 'good practice' as evidence of misconduct, evidence that, in turn, that could be used as a ground to remove a trustee (Maloney 2015, pp. 1-2).

\section{The Expansion of Indirect Intersections between Counterterrorism and Charity Law before and after $9 / 11$}

As the category of indirect intersection subsumes terrorist organizations or activities under broader concepts (such as an 'unlawful' group or activity) we naturally find most continuity from previous legal regimes for the combat of terrorism. The majority of countries have revised, built on and expanded pre-existing norms embedded in criminal codes or public order acts. Only Canada and New Zealand did not have existing counterterrorism legislation prior to 9/11 (see Table 2, below).

To do justice to the complexity of indirect intersections, we discuss how a terrorist group or organization is defined, and how support for them is criminalized, illustrating the importance of this category. We start with Canada and New Zealand, which post-9/11 criminalized support for terrorist groups rather than banning these organizations. This is followed by a discussion of the US, which shares this emphasis, but created similar indirect intersections (as the case with direct intersections) in the 1990s. The last three countries (Australia, the UK and Ireland) have had provisions to proscribe (mostly 'unlawful') organizations for many decades, and reinforced existing laws post 9/11.

Since 2001, article 83.05 of the Canadian Criminal Code 1985 has allowed the Governor in Council to maintain a list of entities that are engaged in terrorism, facilitate it, or act on behalf of such an entity. The definition of terrorist activity (and thus of a terrorist group 'facilitating terrorist activity') is broad, including 'being an accessory after the fact or counselling in relation to any "terrorist activity"' (83.01(1); Carter 2011, p. 12; see Appendix A). It is not a crime to be listed but a listed entity's property can be confiscated. 
Furthermore, it is an offence to knowingly participate in or contribute to, directly or indirectly, any activity of a terrorist group. Amendments to the Criminal Code introduced by the Anti-Terrorism Act 2015 further created the offence of knowingly advocating or promoting the commission of terrorism offences in general (83.221). Facilitating terrorist activities is punished with a maximum of 14 years' imprisonment (see 83.19). Importantly, it has been argued that 'facilitation' itself does not presuppose knowledge of a particular terrorist activity (see 83.19(2); Bloodgood and Tremblay-Boire 2011, p. 159; Carter 2004). Article 83.08 of the Criminal Code prohibits dealing with property directly or indirectly owned or controlled by a terrorist group. While this provision suggests that knowledge is a precondition to commit an offence, ignorance is only excused if 'all reasonable steps' have been made to gather information about who owned the property. Penalties for violating these rules are fines up to $\$ 100,000$ CAD or up to 10 years' imprisononment (83.12).

The Terrorism Suppression Act 2002 in New Zealand introduced new regulations for designating terrorist organizations and entities associated with them (s. 22), to prohibit dealings with such entities rather than suppressing them as such. Like Canada, New Zealand thereby fulfilled its international obligations under United Nations Security Council Resolution 1373 (2001), as well as the international terrorism conventions New Zealand is signatory to. This Act created four offences directly relevant to charities: prohibiting dealing with the property of a designated organization (s. 9), making property or financial support available to such an organization (s. 10), recruiting members for the group (s. 12) and participating in the group (s. 13). The maximum sanction is 14 years imprisonment for each offence. All four offences presuppose knowledge of the group being designated, with the last-mentioned offence, participation, also requiring an intention to facilitate terrorist acts (Conte 2010, p. 614). The provision of property or financial services to designated organizations must be made 'wilfully and without lawful justification or reasonable excuse' (s. 10). While the formulation suggests that a combination of reckless behaviour and lack of knowledge due to gross neglect might constitute an offence, the threshold for committing an offence is higher than in Canada where the intent/knowledge requirements have been relaxed and partially removed. At the same time, however, the definition of 'terrorist act' is fairly specific, explicitly excluding protest, advocacy, or dissent, engagement strikes, lockout, or other industrial action (s. 5(5)), and humanitarian assistance to a designated terrorist 
individual in need is explicitly considered as a 'reasonable excuse' (10(3)). That said, the New Zealand Justice Ministry has signalled that the Anti-Money Laundering and Countering Financing of Terrorism Act 2009, which came into full force in June 2013 may apply to some charitable entities. This would require them to undertake risk assessments, conduct due diligence and account monitoring and report suspicious transactions to the police (Mackintosh and Duplat 2013, p. 34). New Zealand's Charities Services also monitors charities on a risk-basis for terrorism. ${ }^{23}$

The US has also traditionally not aimed at outlawing organizations but has focused on the activities of organizations' members (with mere membership of an organization being insufficient to constitute an offence) (Tushnet 2009). Yet, unlike in Canada and New Zealand, the bombing of the World Trade Center predominantly led to the reinforcement of legal provisions against charities with ties to terrorism that had already been introduced in response to earlier attacks. Notably, the Antiterrorism and Effective Death Penalty Act 1996 (AEDPA), which passed in the aftermath of the Oklahoma City bombing (1995), enabled the Secretary of State to create a list of designated foreign terrorist organizations (s. 1189) and made it a crime to raise and contribute funds, to donate educational and humanitarian supplies, or to provide lodging, transportation or other forms of 'material support' to such groups, with medicine and religious materials specified as the only exceptions (s. 1182). The last provision was particularly criticized for criminalizing the legal, political, or charitable activities of groups, constituting 'guilt by association' and thereby unintentionally affecting a large number of charitable organizations in the US (Pearson 1998, pp. 1211-12). Post 9/11, the Patriot Act facilitated proscription and broadened the range of terrorist offences for which the government could seize assets as well as the scope of 'material support or resources' (e.g. to expert advice or assistance to terrorist organizations, training) (18 U.S.C. $\S 2339 \mathrm{~A}(\mathrm{~b})(1))$. While the exceptions to 'material support' made in the AEDPA are sustained, these provisions still establish wide-ranging discretion and - due to their breadth - do not require proof that individuals intended to support terrorism. Later revisions have underscored the absence of a specific intent requirement in the legislation, with the only requirement being that the donor or supporter knows that the recipient is a designated

${ }^{23}$ https://charities.govt.nz/charities-in-new-zealand/making-a-complaint/, accessed January 30 2017. 
foreign terrorist organization or engages in terrorist activity (Bloodgood and Tremblay-Boire 2011, p. 150). The Act expanded penalties for material support to a maximum of 15 years' imprisonment, and if someone dies as a result of the activity, to a life sentence for the offender. In 2002, the financing of terrorism, that is, 'to wilfully amass funds for terrorist activities' was officially prohibited, sanctioned by up to 20 years' imprisonment. Furthermore, charities suspected of being involved in terrorist financing can be designated based on Executive Orders 12947 (1995) and 13224 (2001). US charities are prohibited from dealing with and receiving contributions from designated organizations. More specifically, Executive Order 13224 allows for the blocking of assets of organizations that are 'controlled by' or 'otherwise associated' with listed entities (s. 1 (d)(ii)), and prevents the provision of funds or goods including humanitarian donations such as clothes or food (s. 4). Executive Order 13224 does not include a 'knowledge' or an 'intent' clause, leaving organizations vulnerable to charges of supporting terrorist organizations whose nature they were not aware of (Bloodgood and Tremblay-Boire 2011, p. 150).

Moving to jurisdictions with long-established proscription regimes, in Australia, provisions that allow for the banning of 'unlawful organizations' go back to the Crimes Act 1914 and are still in force (Part IIA). ${ }^{24}$ While the concept of 'unlawful organizations' covers terrorist organizations and has its own range of sanctions attached to it, by 2002 two additional legislative regimes were established with a strong focus on those supporting such organizations. Designed to meet Australia's international counterterrorism obligations (Attorney-General 2016), the definition of terrorism drew heavily on the UK Terrorism Act 2000 (Mackintosh and Duplat 2013, p. 23).

The first regime is specified in the Suppression of the Financing of Terrorism Act 2002, criminalizing the direct or indirect dealing with assets listed, owned or controlled by a proscribed person or entity. Under this regime, asset holders - which can include charities are not liable if they act in good faith and without negligence (Conte 2010, p. 590). The second regime, which has raised more debate and led to a number of criminal prosecutions, amended the Criminal Code 1995, setting out the process of how to proscribe a terrorist

\footnotetext{
${ }^{24}$ The Crimes Act 1914 (Cth) was amended in 1926 to ban unlawful revolutionary associations (Douglas 2001).
} 
organization in more detail, plus a range of 'derivative' offences against those who are involved with them (carrying prison sentences from 3 to 25 years) (Lynch et al 2009, pp. 45). The Criminal Code Amendment (Terrorist Organisations) Act 2004 gives the AttorneyGeneral discretion to proscribe organizations on a range of grounds including 'planning' or 'advocating' terrorist acts (Division 102, Criminal Code 1995) and the status of being listed has severe consequences for supporters of an organization. 'Informal membership' is sufficient to commit an offence, a condition that might be met by attending a meeting. An association offence can be committed by a person through mere communication with an 'informal member' - presupposing the person knows the latter is providing support to a terrorist organization (Lynch et al. 2009, pp. 18-19). Despite this knowledge requirement, the vagueness of what 'association' means, in conjunction with the vagueness of who qualifies as a member, creates considerable legal uncertainty. And while the Criminal Code excludes situations such as the provision of humanitarian aid (Division 102-8(4)(c)), Mackintosh and Duplat have highlighted that 'in Australia, recklessness as to whether the group is listed is sufficient. This significantly increases the possibility that ancillary engagement, or even humanitarian action itself, or could fall foul of the law' $(2013$, p. 43).

Ireland is our third jurisdiction where the possibility to proscribe an organization has existed for many decades. According to the Offences Against the State Act of 1939, an organization can be declared 'unlawful' (s. 18). This is defined broadly, and covers the promotion and advocacy of violent acts, not just their planning and execution, and thus encompasses terrorism. Being a member of an unlawful organization carries a maximum penalty of seven years' imprisonment (Hamilton 2007, pp. 8-9). While the 1939 Act focused on disabling the suppressed organization by removing property etc., in later amendments the focus shifted towards expanding derivative offences. For instance, 1985 amendments criminalized holding or collecting money to support unlawful organizations. Similarly, the Offences against the State (Amendment) Act 1998 added offences such as the unlawful collection of information (s. 8). Post 9/11, the 2005 the Criminal Justice (Terrorist Offences) Act added terrorism as an explicit ground to suppress an organization (Hamilton 2007, p. 15). ${ }^{25}$ No

\footnotetext{
${ }^{25}$ As an immediate response to UNSCR 1373, the EU adopted the Council Common Position of 27 December 2001 which, among other provisions, ordered the freezing of assets and the prevention of
} 
previous act defined or used the term 'terrorist' or 'terrorist related activities'. It also created a new offence of financing terrorism, establishing a scheme for freezing and confiscating funds used or gained in connection with terrorist activity (s. 13). The list of criminalized activities was further extended in 2012 and 2015. That said, the 2005 the Criminal Justice (Terrorist Offences) Act simultaneously created exceptions to permit protest, advocacy, dissent, strikes, lock-outs or other industrial action (Hamilton 2007, p. 16), preventing the criminalization of these activities (s. 6 (5)). Similarly, knowledge requirements remain intact. For instance, providing assistance to a terrorist organization constitutes an offence only if such assistance is rendered 'knowingly' (21.A (1)). Similar qualifications exist with respect to the new offences in the Criminal Justice (Terrorist Offences) (Amendment) Act 2015 of public provocation, recruitment and training, each of which must be committed 'intentionally' (ss. 4-6).

In the UK, provisions for proscription have existed since the Public Order Act 1936, which criminalizes the management, involvement in or support of associations established 'for the use or display of physical force in promoting any political object' (s. 2). Responding to violence triggered by the Northern Ireland conflict, legal mechanisms to ban organizations have been revised at various times over the last several decades and have been used as tools to assure public safety from early on (Bourne 2014). Nonetheless, we find some significant shifts in the 2000s. Under the Terrorism Act 2000, the Secretary of State can list an organization if 'the organisation is concerned in terrorism': in that it 'commits or participates in acts of terrorism', 'prepares for terrorism', 'promotes or encourages terrorism', or 'is otherwise concerned in terrorism' (s. 3). The phrase 'otherwise concerned in terrorism' has been criticized as a catch-all, providing the Secretary of State with extensive leeway to prosecute (Conte 2010, p. 593). It further created three derivative offences regarding proscribed organizations: membership in, (non-financial) support of, and the wearing of uniforms or emblems of a proscribed organization. Particularly important to charities, terrorist property is defined very broadly as 'money or other property which is likely to be used for the purpose of terrorism' (s. 14). There is a duty to report a suspicion of terrorist property offences to the police. The maximum sentence for these offences is 14

resources being made available to 'persons, groups and entities involved in terrorist acts' (Regulation (EC) 2580/2001), which shaped legislative responses in the UK and Ireland. 
years' imprisonment. While similar provisions in other countries presuppose knowledge of the nature of such property, UK legislation relaxes this requirement considerably by adding the qualification 'having reasonable cause to suspect' (Conte 2010, pp. 231-2; Bloodgood and Trembay-Boire 2011, p. 155) and does it allow any exceptions for humanitarian activities (Mackintosh and Duplat 2013, p. 40). The Terrorism Act 2006 (enacted following the 2005 London terrorist bombings) further added the 'glorification' of terrorism as a ground for proscription (s. 1 (3)), defining glorification through a broad range of generalized statements such as 'praise' or 'celebration' (s. 20 (2)), introducing a breadth and definitional vagueness that has been widely problematized (Ekaratne 2010, p. 207). Since the Terrorist Asset-Freezing etc. Act 2010, we further find a separate process for designation leading to a designated organization's freezing of assets (s.11)), while criminalizing various forms of material support for the latter (ss. 12-15)).

Table 2, below, summarises the broad patterns in the introduction or expansion of legal connections between charity and counterterrorism law in our six democracies. Overall, instances of overlap and direct intersections - particularly visible types of legal change were mainly introduced post $9 / 11$. Such mechanisms are attractive in a period when many governments felt pressed to adopt legislation with great speed to signal an effective response to the urgency and severity of the terrorist threat (thereby often downplaying parliamentary scrutiny creating its own normative problems) (Carne 2008; Neal 2012). Regarding cross-national differences, Canada has experienced the most pronounced shift in its legal framework. Legislators created new connections between charity and counterterrorism laws across all three categories. While not having experienced any attack on home soil resulting in mass casualties on a scale comparable to the US, the readiness in Canada to actively legislate has been attributed to its geographic proximity and willingness to emulate legislative action in the US (Roach 2015, pp. 361-2). Similarly, New Zealand (not yet having suffered any serious terrorist attacks) has adopted provisions creating new direct and indirect intersections, but has established fewer than Canada in each category. As far as the changes in the legal environment created through newly introduced mechanisms (especially explicit and visible connections between counterterrorism and charity law) impose adaptation costs on charities, in the post 9/11 phase these were most pronounced in Canada. 
Table 2: Connections between Charity and Counterterrorism Legislation - Types of Change

\begin{tabular}{|l|l|l|l|l|}
\hline & Overlap & $\begin{array}{l}\text { Direct } \\
\text { Intersection }\end{array}$ & $\begin{array}{l}\text { Indirect } \\
\text { Intersection }\end{array}$ & $\begin{array}{l}\text { Legislative Shifts } \\
\text { post 9/11 }\end{array}$ \\
\hline United States & $\begin{array}{l}\text { Adopted post } \\
9 / 11\end{array}$ & $\begin{array}{l}\text { Reinforced post } \\
9 / 11\end{array}$ & $\begin{array}{l}\text { Reinforced post } \\
9 / 11\end{array}$ & $\begin{array}{l}\text { Mix revision / new } \\
\text { legislation }\end{array}$ \\
\hline Canada & $\begin{array}{l}\text { Adopted post } \\
9 / 11\end{array}$ & $\begin{array}{l}\text { Adopted post } \\
9 / 11\end{array}$ & Adopted post 9/11 & New legislation \\
\hline New Zealand & $\mathrm{n} / \mathrm{a}$ & $\begin{array}{l}\text { Adopted post } \\
9 / 11\end{array}$ & Adopted post 9/11 & New legislation \\
\hline Ireland & $\mathrm{n} / \mathrm{a}$ & $\begin{array}{l}\text { Adopted post } \\
9 / 11\end{array}$ & $\begin{array}{l}\text { Reinforced post } \\
9 / 11\end{array}$ & $\begin{array}{l}\text { Mix revision / new } \\
\text { legislation }\end{array}$ \\
\hline Australia & $\mathrm{n} / \mathrm{a}$ & $\begin{array}{l}\text { Adopted post } \\
9 / 11\end{array}$ & $\begin{array}{l}\text { Reinforced post } \\
9 / 11\end{array}$ & $\begin{array}{l}\text { Mix revision / new } \\
\text { legislation }\end{array}$ \\
\hline $\begin{array}{l}\text { United } \\
\text { Kingdom }\end{array}$ & $\mathrm{n} / \mathrm{a}$ & $\begin{array}{l}\text { Adopted post } \\
9 / 11\end{array}$ & $\begin{array}{l}\text { Reinforced post } \\
9 / 11\end{array}$ & $\begin{array}{l}\text { Mix revision / new } \\
\text { legislation }\end{array}$ \\
\hline
\end{tabular}

In the remaining jurisdictions 'reinforcement' (a mix of revisions and new legislation) characterizes legal change post-9/11. The US, UK and Ireland strengthened legal regimes initially introduced as responses to internal terrorism, with US and UK changes becoming more pronounced after both democracies suffered from international attacks. Australia stands out somewhat. As with New Zealand and Canada, it has been spared from major attacks (internal or international) so far, but (as with the UK and Ireland) it has a decadesold proscription regime which it considerably reinforced post 9/11.

As highlighted in the above analysis, and despite the different patterns of adaption before and after 9/11, one important parallel across jurisdictions (with and without proscription regimes in place prior to 2001) is the enhanced focus on criminalizing support for terrorism post-9/11. This aspect is particularly crucial when considering (rather than the scope of change and charities' relative adaptation costs) the overall constraints applicable to charities inherent in current legislative regimes, an assessment that we turn to now.

\section{Conclusion: Combating Terrorism by Constraining Charities?}

Using an organization-centred perspective rather than focusing on specific areas of law allowed us to identify the range of counterterrorism laws that applied, both directly and indirectly, to charities in each jurisdiction. This, in turn, facilitated a systematic and unbiased 
comparison of charities' legal environments. To engage in this analysis, we distinguished between three types of legislative connection: overlap, direct intersection, and indirect intersection, analytical categories that differ in terms of the directness and visibility of the connection established between counterterrorism and charity law.

Based on the above assessment, what can we conclude about the way in which laws to counter terrorism constrain the activities of charities in our six countries? As summarized in Table 3 below, which shows instances of overlap, direct intersection and indirect intersection, the repertoire of counterterrorism legislation that applies to charities is broadest, and its constraints most pronounced, in the US. Canada, Australia and the UK take a middle position, while Ireland and New Zealand have the smallest repertoire and impose relatively fewer legislative constraints on their charitable organizations. As highlighted earlier in the analysis, the most visible connections - overlap and direct intersection - are not necessarily the most problematic for charities. The Charity Registration (Security Information) Act in Canada, an instance of overlap, illustrates this. Unlike the US AntiTerrorism Certification process it has a very narrow focus and does not affect charities' actual day-to-day operations by requiring them to vet personnel and partners to sustain government financial support (see above, p. 11). We also find important variation within categories. Considering direct intersections, in New Zealand and Ireland these provisions only refer to charity registration. Regulators are not given explicit rights to monitor charities for the purpose of assuring compliance with counterterrorism law. In contrast, in Australia, the UK, Canada and US direct intersections concern the monitoring of charities' compliance, potentially affecting their day-to-day operations after having been legally recognized. ${ }^{26}$

\footnotetext{
${ }^{26}$ The level of monitoring is, however, inevitably affected by the monitoring organization's resources, notwithstanding any formal legal provisions (see for example ANAO 2011).
} 
Table 3: Types of Legal Constraints Applicable to Charities in Current Legislation

\begin{tabular}{|l|l|l|l|l|l|l|l|}
\hline & \multicolumn{2}{|c|}{ Overlap } & \multicolumn{2}{c|}{ Direct Intersection } & \multicolumn{2}{l|}{ Indirect Intersection } \\
\hline & $\begin{array}{l}\text { Constraints } \\
\text { on } \\
\text { Registration }\end{array}$ & $\begin{array}{l}\text { Constraints } \\
\text { on } \\
\text { Operation } \\
\text { (finance) }\end{array}$ & $\begin{array}{l}\text { Constraints } \\
\text { on } \\
\text { Registration }\end{array}$ & $\begin{array}{l}\text { Constraints on } \\
\text { Operation } \\
\text { (monitoring) }\end{array}$ & $\begin{array}{l}\text { Knowledge } \\
\text { Require- } \\
\text { ment } \\
\text { Removed }\end{array}$ & $\begin{array}{l}\text { Knowledg } \\
\text { e Require- } \\
\text { ment } \\
\text { Restricted }\end{array}$ & $\begin{array}{l}\text { Knowledge } \\
\text { Require- } \\
\text { ment } \\
\text { Sustained }\end{array}$ \\
\hline United States & $\mathrm{X}$ & $\mathrm{X}$ & $\mathrm{X}$ & $\mathrm{X}$ & $\mathrm{X}$ & & \\
\hline Canada & $\mathrm{X}$ & & & $\mathrm{X}$ & $\mathrm{X}$ & & \\
\hline UK & & & $\mathrm{X}$ & $\mathrm{X}$ & & $\mathrm{X}$ & \\
\hline Australia & & & $\mathrm{X}$ & $\mathrm{X}$ & & $\mathrm{X}$ & \\
\hline New Zealand & & & $\mathrm{X}$ & & & & $\mathrm{X}$ \\
\hline Ireland & & & $\mathrm{X}$ & & & & $\mathrm{X}$ \\
\hline
\end{tabular}

Note: We consider whether overlap and direct intersection only target charity registration or also regulate aspects that concern their day-to-day operations post-registration. Regarding indirect intersections, we focus on the relaxation or removal of knowledge criteria to commit an offence as central element and, for the sake of clarity, refer to the most significant restriction within each jurisdiction (rather than different restrictions that might co-exist).

Due to their scope and complexity, the constraints generated through indirect intersections between counterterrorism and charity law are most difficult to assess cross-nationally. Counterterrorism laws in each of the six democracies examined carry substantial penalties for derivative offences (for example, associating with a proscribed group or its members, or dealing with its property) that range from three to 25 years' imprisonment. While sanctions send an important signal about the seriousness attributed to certain offences, relative differences in sanctions are less immediately relevant for charities' day-to-day operations than the risk of unintentionally committing a terrorism-related offence.

This risk is directly shaped by the potential scope of the offence and the vagueness of the concepts used to circumscribe, for instance, 'terrorist activities'. We find significant leeway in the interpretation of the concepts used to criminalize support for terrorism in all six jurisdictions, which creates considerable uncertainty for charities in their everyday operations. Provisions that have received particular criticism refer to 'material support' (US), 'the facilitation of terrorist activities' (Canada), 'informal membership' of terrorist organizations (Australia) or 'being otherwise concerned in terrorism' (UK). ${ }^{27}$ Also, in Canada and the US some provisions lack explicit knowledge requirements as a condition for committing an offence (in the former related to the facilitation of terrorist activities, in the

\footnotetext{
${ }^{27}$ As noted earlier, legislation in the US, Ireland and New Zealand also specifies exceptions, which provide a more 'clear cut' picture of the scope of counterterrorism offences.
} 
latter regarding terrorist financing), thus, charities can commit offences unknowingly. In both the UK and Australia, knowledge requirements are qualified in provisions regarding terrorist financing, which put a burden of proof on charities to demonstrate that reasonable step are taken to ensure that their funding does not carry any links to terrorism. Especially if linked to vague notions of what constitutes membership of, and association with, terrorist organizations (e.g. Australia), this seems problematic. Only New Zealand and Ireland have knowledge requirements that establish a relatively clear-cut threshold for determining whether charities and their members have committed criminal offences. This supports Golder and Williams (2004, p. 286) who argue that where general approaches to combatting terrorism are taken, they should be underpinned by references to intention and motivation, articulating the spirit of the law. Meanwhile, lawmakers may want to place obligations on organizations to encourage vigilance and disincentivize carelessness. A counterbalance could be provided by explicitly excluding humanitarian or otherwise legitimate and legal activity (protest, advocacy, industrial relations) from general concepts such as 'facilitating terrorist activity' (provisions found in New Zealand or Ireland), to enable charities to assess when they operate on legal grounds and when not.

Overall, our analysis suggested that it is through indirect intersections, which are least visible and most vague that the day-to-day activities of charities are most affected (particularly acute in the case of derivative offences related to the support of terrorism). This has important empirical and normative repercussions. From a process driven perspective, it suggests that extensive consultative and participatory policy-making mechanisms (see McConnell 2010, p. 198) may not be sufficient to avoid unintended consequences when the reach of the law is potentially extremely broad. Charities have responded to legal uncertainties, referred to as the 'shadow of the law effect', by preemptively withdrawing from some of the activities (especially international) that could bring them in conflict with counterterrorism legislation (Carter 2004, p. 1; Bloodgood and Tremblay-Boire 2011). Other studies have stressed that international aid charities are struggling to use their donations for frontline services due to stricter counterterrorism legislation, which prompts banks to shut down accounts in an effort to reduce their overall risk. Similarly, Muslim charities and charities working in conflict zones have suffered financial losses due to fewer private donations (Burniske 2014; Keatinge 2014; Cole 2016). 
The significant legislative shifts post $9 / 11$ as well as the legal constraints currently applicable to charities in the six democracies analysed echo broader critiques of counterterrorism legislation. The latter, some argue, risk fundamentally changing the relationship between the individual and the state (Haubrich 2006). Building on the analyses conducted here, more research needs to done on the actual impact of existing legislative connections between counterterrorism and charity law, especially as we have again seen significant legislative change in the last few years. Such endeavours link legal and public policy analysis on the one hand and the political science literature on the other, as implementation can be looked at from the perspective of the state or of charities (e.g. Bloodgood and Tremblay-Boire 2011). Thus, one challenge will be to study whether (and how) the legislative frameworks assessed here are used, implemented and interpreted by government authorities and how they are complemented by non-statutory areas of charity regulation, including judicial decisions and voluntary guidance. Another challenge will be to study how charities respond to new legal realities, whether they withdraw from certain activities overseas, further professionalize to meet enhanced managerial demands to vet their partners and personnel to assure compliance with increasingly burdensome legal requirements, or whether they challenge the application of this legislation in the courts. To address these themes goes beyond the scope of this paper. Yet the insights provided in how charity and counterterrorism law have become increasingly inter-related in the long-lived common law democracies constitute a sound foundation for such analyses.

Acknowledgements: We thank Felix-Christopher von Nostitz and Patricia Correa Vila for their research assistance and their feedback on earlier versions of this paper. We also thank the participants in the panel 'Defending Democracy through Counter-Terrorism Legislation?' at the PSA Annual Conference in Sheffield 2015, where we presented an early version of this article, for their input. Finally, we are grateful to the three referees and the editor of this journal for their suggestions how to revise the paper. All remaining errors are ours.

Funding: This research has received funding from a BA/Leverhulme Small Research Grant (SG-132160) and from the European Research Council under the European Union's Seventh 
Framework Programme (FP7/2007-13)/ERC grant agreement 335890 STATORG). This support is gratefully acknowledged.

\section{References}

ANAO [Australian National Audit Office] (2011). Administration of Deductible Gift-Recipients (Nonprofit Sector). Canberra: Commonwealth of Australia.

Attorney-General [Australian Government] (2016). International counter-terrorism measures, https://www.ag.gov.au/NationalSecurity/Counterterrorismlaw/Pages/Internationalcounterterrorism measures.aspx, 13 December 2016.

Baron, B. F. (2004). Deterring Donors: Anti-Terrorism Financing Rules and American Philanthropy, The International Journal of Not-for-Profit Law, 6 (2).

Bater,P., F. Hondius \& P. K. Lieber (2004). (eds) The Tax Treatment of NGOs, Kluwer.

Bauer, Michael W., Jordan, Andrew, Green-Pedersen, Christoffer, Héritier, Adrienne (eds.) (2012). Dismantling Public Policy: Preferences, Strategies, and Effects. Oxford: Oxford University Press.

Bauer, M. W. \& C. Knill (2014). A Conceptual Framework for the Analysis of Policy Change: Measurement, Explanation and Strategies of Policy Dismantling. Journal of Comparative Policy Analysis, 16 (1), 28-44.

Bell, J. L. (2008). Terrorist Abuse of Non-Profits and Charities: A Proactive Approach to Preventing Terrorist Financing, https://law.ku.edu/sites/law.drupal.ku.edu/files/docs/law_journal/v17/bell.pdf, March 152015.

Bloodgood, E.A. \& J. Tremblay- Boire (2011). International NGOs and National Regulation in an Age of Terrorism. VOLUNTAS: International Journal of Voluntary and Non-Profit Organizations 22(1), 142173.

Biezen I.v. (2012) Constitutionalizing Party Democracy: The Constitutive Codification of Political Parties in Post-War Europe, British Journal of Political Science 42: 187-212.

Blacher, G. (2016). ACFID: Aid Charities have Zero Tolerance for Terrorism, https://thirdsector.com.au/53840-2/, 14 December 2016.

Bourne, A. (2014). Security or Tolerance? The Proscription of Political Parties in Democratic States. Paper presented at the ECPR Joint Sessions in Salamanca, April 102014.

Boyne, S. (2004). Law, Terrorism, and Social Movements: The Tension between Politics and Security in Germany's Anti-Terrorism Legislation, Cardozo Journal of International and Comparative Law12 (1), 41-82.

Bricknell, S. (2011). Misuse of the Non-Profit Sector for Money Laundering and Terrorist Financing, Trends \& Issues in Crime and Criminal Justice, No. 424, September 2011, Australian Institute of Criminology, 1-6. 
Burniske, J. (2014). Counter-terrorism Laws and Regulations: What aid agencies need to know, Network Paper Nr. 79. HPN.

Carne, G. (2008) Hasten Slowly: Urgency, Discretion and Review -A Counterterrorism Legislative Agenda and Legacy, Deakin Law Review 13 (2), 49-99.

Carter, T. S. (2004). Charities and Compliance with Anti-Terrorism Legislation: The Shadow of the Law, National Center on Philanthropy and the Law $16^{\text {th }}$ Annual Conference, New York - October 2829.

Carter, T.S. (2011). Charities and the Anti-Terrorism Financing/ Money Laundering Regime, Osgoode Hall Law School CLE Program, October 62011.

Charities Services (NZ) (2016). Protecting against terrorism and money-laundering, https://www.charities.govt.nz/im-a-registered-charity/running-your-charity/protecting-againstterrorism-and-money-laundering/, November 132016.

Charity Commission of England and Wales (2015). Tackling Abuse and Mismanagement 2014-15, https://www.gov.uk/government/publications/tackling-abuse-and-mismanagement-201415/tackling-abuse-and-mismanagement-2014-15-full-report, October 302016.

Conte, A. (2010). Human Rights in the Prevention and Punishment of Terrorism: Commonwealth Approaches: The United Kingdom, Canada, Australia and New Zealand, Springer: Heidelberg.

Cortright, D. Millar, A., Gerber-Stellingwerf, L.; and G. A. Lopez (2012). Friend, Not Foe: The Role of Civil Society in Preventing Violent Extremism, Notre Dame Journal of International \& Comparative Law 2 (2), 238-56.

Cole, A. (2016). Charities and terrorism: 'deadly threat' or a distraction from real issues facing sector? The Guardian Febuary 9 2016, https://www.theguardian.com/voluntary-sectornetwork/2016/feb/09/charities-terrorism-deadly-threat-distraction-sector, October 302016.

CRA [Canada Revenue Agency] (2016a). Revocation as a result of an audit, http://www.craarc.gc.ca/chrts-gvng/chrts/rvkng/typs/rvk-dt-eng.html, April 182016.

CRA [Canada Revenue Agency] (2016b). Provincial and territorial government information for charities, http://www.cra-arc.gc.ca/chrts-gvng/chrts/prvncs/menu-eng.html, 13 December 2016.

CRA [Canada Revenue Agency] (2016c). Revoked Canadian charity listed under the Criminal Code as terrorist entity, http://www.cra-arc.gc.ca/chrts-gvng/chrts/whtsnw/trrrst-ntty-eng.html, October 30 2016.

Douglas, R. (2001). Keeping the Revolution at Bay: The Unlawful Associations Provisions of the Commonwealth Crimes Act, Adelaide Law Review 22: 259-297.

Ekarante, C. (2010). Redundant Restriction: The U.K.'s Offense of Glorifying Terrorism, Harvard Human Rights Journal 23 (1), 205-21.

Freeman, M. (2011). The Sources of Terrorist Financing: Theory and Typology, Studies in Conflict \& Terrorism 34 (6): $461-475$. 
Garton, J. (2009). The Regulation of Organised Civil Society. London: Hart Publishing.

Gerring, J. (2007). Case Study Research: Principles and Practices. Cambridge: Cambridge UP.

Golder, B. and G. Williams (2004) What is 'Terrorism'? Problems of Legal Definition, UNSW Law Journal 27(2): 270-295.

Goodstein, L. (2008). U.S. Muslims Taken Aback by a Charity's Conviction, The New York Times, November 25, 2008.

Hamilton, J. (2007). The Interplay between EU and Domestic Counter-terrorism Laws, ERA-ICEL Seminar, Dublin, 2 November 2007, https://www.dppireland.ie/filestore/documents/ERAICEL Seminar Speech 021107 Amended.pdf, March 152015.

Haubrich, D. (2006). Anti-terrorism Laws and Slippery Slopes: A Reply to Waddington, Policing and Society: An International Journal of Research and Policy 16 (4), 405-14.

Hayes, B. and I. McAllister (2005). Public Support for Political Violence and Paramilitarism in Northern Ireland and the Republic of Ireland, Terrorism and Political Violence 17: 607-8.

Hopkins, B. R. (2008). IRS Audits of Tax-Exempt Organizations: Policies, Practices, and Procedures, Hoboken: John Wiley and Son.

Hopt, K. J. \& T. von Hippel (eds) (2010). Comparative Corporate Governance of Non-Profit Organizations, Cambridge: Cambridge UP.

Howell, J. (2006). The Global War on Terror, Development and Civil Society, Journal of International Development 18, 121-35.

Howell, J. (2012) Shifting Global Influence on Civil Society: Times for reflection, in: H, Moksnes and M. Melin (eds.) Global Civil Society, Uppsala: Uppsala Centre for Sustainable Development, pp. 43-62.

Jackson, B.A.J, J. C. Baker, P. Chalk, K. Cragin, J. V. Parachini, H. R. Trujillo (2005) Aptitude for Destruction, Volume 2. Case Studies of Organizational Learning in Five Terrorist Groups. Pittsburgh: Rand Corp.

Keatinge, T. (2014). Uncharitable Behaviour. London: Demos.

Krahmann, E. (2005). From State to Non-State Actors: The Emergence of Security Governance, Berlin: Springer.

Lombart, G. A. (2011). The Political of Suppression: Eamon de Valera's Government and the IRA, 1938-1941. Unpublished PhD Thesis, University of Maine.

Lynch, A. N. McGarrity and G. Williams (2015). Inside Australia's Anti-Terrorism Laws and Trials. Sydney: New South Publishing.

Lynch, A. N. McGarrity and G. Williams (2009). The Proscription of Terrorist Organizations in Australia, Federal Law Review, http://www.gtcentre.unsw.edu.au/sites/gtcentre.unsw.edu.au/files/mdocs/Prosciption.pdf, March 152015. 
Mackintosh, K. and P. Duplat (2013). Study of the Impact of Donor Counter-Terrorism Measures on Principled Humanitarian Action. OCHA.

Maloney, J. (2015). Protection of Charities Bill, Farrer\& Co LLP, http://www.farrer.co.uk/Global/Briefings/Protection\%20of\%20Charities\%20Bill.pdf, March 192016.

Marsh, D. and A. McConnell (2010). Towards a Framework for Establishing Policy Success, Public Administration 88 (2): 564-583.

McConnell, A. (2010). Understanding Policy Success: Rethinking public policy. Basingstoke: Palgrave Macmillan.

Moor, Keith (2010). 'Charity used as a front to finance Sri Lanka's Tamil Tigers', Herald Sun, 2010-0401, www.heraldsun.com.au/news/charity-used-as-front-to-finance-sri-lankas-tamil-tigers/storye6frf7jo-1225848229678, October 302016.

Neal, A. W. (2012). Terrorism, Lawmaking, and Democratic Politics: Legislators as Security Actors, Terrorism and Political Violence 24 (3), 357-374.

NCVO (2009). Counter-Terrorism and Civil Society: What are the effects of the 'War on Terror' and counter-terrorism measures on civil society?,

http://www.Ise.ac.uk/internationalDevelopment/research/NGPA/publications/Counter-

terrorism\%20and\%20civil\%20society\%20final\%20version.pdf, October 302016.

Nohrstedt, D. and D. Hansén (2010). Converging under Pressure? Counterterrorism Policy Developments in the European Union Member States, Public Administration 88 (1): 190-210.

O'Halloran, K. (2011). The Politics of Charity, London: Routledge.

Pearson, A. (1998). The Anti-Terrorism and Effective Death Penalty Act of 1996: A Return to Guilt by Association, William Mitchell Law Review 24 (4): 1185-1215.

Raphaeli, N. (2003) Financing of Terrorism: Sources, Methods, Channels, Terrorism and Political Violence 15 (4): 59-82.

Roach, Kent (2015). The 9/11 Effect. Cambridge: Cambridge University Press.

Rutzen, Douglas (2015) Aid Barriers And The Rise Of Philanthropic Protectionism, International Journal of Not-for-Profit Law 17 (1): 1-44.

Salamon, L.M. (eds.) (1997). The International Guide to Nonprofit Law, New York Wiley.

Sidel, M. (2010). Regulation of the Voluntary Sector: Freedom and Security in an Area of Uncertainty, London: Routledge.

Sitter, N. and T. Parker (2014). Fighting Fire with Water: NGOs and Counterterrorism Policy Tools, Global Policy 5 (2): 159-167.

Thiel, M. (ed.) (2009). The 'Militant Democracy Principle' in Modern Democracies, London: Ashgate.

Tosini, D. (2007). Sociology of Terrorism and Counterterrorism: A Social Science Understanding of Terrorist Threat, Sociology Compass 1/2: 664-81. 
Tushnet, M. V. (2009). The United States of America, in: Thiel, M. (ed.) The 'Militant Democracy Principle' in Modern Democracies, London: Ashgate, pp.357-78.

Young, N. M. (2013). Charity Commission Condemns 'Abhorrent' Abuse of Muslim Aid by Terror Plotters, CivilSociety.co.uk.

Zweigert, K. \& H. Kötz (1998). Introduction to Comparative Law. Oxford: Clarendon Press.

6, P. (2014). Explaining Unintended and Unexpected Consequences of Policy Decisions: Comparing Three British Governments, 1959-74, Public Administration 92 (3): 673-691. 